\title{
Andrzej Zbieć
}

mgr inż.

Instytut Kolejnictwa

azbiec@ikolej.pl

\section{Grzegorz Wysocki}

mgr inż.

Instytut Kolejnictwa

gwysocki@ikolej.pl

DOI: $10.35117 / \mathrm{A} \_E N G \_17 \_09 \_01$

\section{Dynamic research of rolling stock}

\begin{abstract}
The paper presents the development of research methods in the fi eld of dynamic research of rolling stock in historical perspective as well as the genesis of today's dynamics and safety studies and impact on the track, taking into account the admissible values for particular parameters. Measuring techniques developed by the Railway Research Institute to measure Q (vertical) and $\mathrm{Y}$ (transverse) forces in the wheel-rail contact area has been discussed. Basic assumptions of dynamic tests on the railway network were mentioned. The methods of measuring data processing and the evaluation of results as well as examples of graphical results were presented.
\end{abstract}

Keywords: Transport; Rail vehicles; Dynamics

\section{Development of researching methods}

Issues about research of dynamic trip were raised over the yeras by authors [1]. One of the fields, being for many years subject of researches in passenger rail vechicles, was research of influence of vibration resulting from movement of rolling stock on passengers feelings (initially without any consideration of time exposure on vibration influence). Affiliated railways in UIC for this purpose were using for calculate a calmness factor run $\mathrm{Wz}$ which is a combination of frequency and amplitude of vibration for every discrete frequencies, identyfied with help of Fourier's rapid transformation. Calculated value of calmness factor run Wz estimated according to tab. 1.

Tab. 1. Evaluation of vibration impact on the basis of the calmness coefficient of the run $W_{z}$

\begin{tabular}{|c|l|}
\hline $\mathrm{W}_{\mathrm{z}}$ & \multicolumn{1}{|c|}{ Ocena } \\
\hline 1 & barely noticeable \\
\hline 2 & clearly felt \\
\hline 2,5 & strong but still comfortable \\
\hline 3 & strong, unpleasant, but still tolerated \\
\hline 3,25 & very unpleasant \\
\hline 3,5 & extremely unpleasant, annoying, not tolerated with prolonged exposure \\
\hline 4 & very annoying, with a longer harmful effect \\
\hline
\end{tabular}

The research of calmness run with determination of $\mathrm{Wz}$ factor became historical archetype for researches:

- of passengers trip comfort according to Chart UIC 513 [2] and norm EN 12299 [5], but the $\mathrm{Wz}$ factor itself has been replaced by Nmv factor (in symplification method) or Nva and Nvd factors (in full method)

- of risk of machinist on influence of vibrations (according to norm PN-EN 14253 [6] and two regulations [10] and [9]); 
- of dynamic and safety of trip and impact on the truck (initially according to Chart UIC 518 [3], but nowadays according to norm PN-EN 14363 [7]).

The two first researches are releated to impact of vibrations to the human body (passengers and machinist) and they are direct continuation of research of run clamness with $\mathrm{Wz}$ factor, while third research - according to the UIC chart title - refers to the rating of dynamic behavior of rolling stock in terms of safety, quality of the run and impact on the truck.

As the research methods develop, appointed by UIC (Union Internationale des Chemins de Fer - Międzynarodowy Związek Kolejowy; since 1922) ORE ( Office des Recherches et d'Essais Ośrodek Badań i Prób; since 1951), later replaced by ERRI (European Rail Research Institute Europejski Kolejowy Instytut Badawczy; since 1992) - as auxiliary bodies for the central leading of researches and experiments, which many of railway managements could not undertake in their own range beacause of high costs of that researches or lack of appropriate researching laboratories - they worked on elaboration of method of behavioral assesment of newly-constructed or upgraded rolling stock during riding on straight line and in curves with different radius. It was about driving speed, truck factor (loose in a truck, vertical and horizontal inequalities, superelevation etc.) and parameters of vehicle itself (construction of the trolley, suspension, construction of body etc.) for its rating during the ride. The first, temporary version of UIC 518 chart was released in July, 1995 and contained only some of nowadays used parameters of rating. However, from very begining they were divided into three groups:

- parameters releated to driving safety

- parameters releated to impact on the truck

- parameters releated to calmness of vehicle run

Based on UIC 518 chart the norm PN-EN 14363 was established, which the first publication was in 2005 (as EN), as translation in Polish in 2007, but nowadays form 2016 is law in force. It should be mentioned that PN-EN 14363 norm was supplemented by PN-EN 16235 norm [8] by conditions for dismissal of some rail car from linear examination according to EN 14363. Applicable Technical Specifications of Interoperability referring to european norms contribute to frequent updates. Latest publication UIC 518 chart is from October, 2009.

In the table No.2 rating parameters from the first publication of UIC 518 chart are compiled (July, 1995) and latest $-4^{\text {th }}$ publication (October, 2009).

Tab. 2. Comparison of parameters I and IV editions of UIC 518 chart

\begin{tabular}{|c|c|c|c|}
\hline \multirow{2}{*}{ Parameter } & \multirow{2}{*}{ I edition } & \multicolumn{2}{|c|}{ IV edition } \\
\hline & & Normal method & Simplified method \\
\hline Driving safety & $\Sigma Y, Y / Q$ & $\Sigma \mathrm{Y}, \mathrm{Y} / \mathrm{Q}, \operatorname{rms}(\Sigma \mathrm{Y}), \eta$ & $\begin{array}{l}\mathrm{H}, \ddot{z}_{S}^{*}, \mathrm{rmsH}, \mathrm{rms} \ddot{y}_{S}, \\
\ddot{y}_{S}^{+}, \ddot{y}_{S}^{*}, \mathrm{rms} \ddot{y}_{S}^{+}\end{array}$ \\
\hline Influence on the track & $\mathrm{Q}, \mathrm{Y}_{\mathrm{qst}}, \mathrm{Q}_{\mathrm{qst}}$, & $\mathrm{Q}, \mathrm{Y}_{\mathrm{qst}}, \mathrm{Q}_{\mathrm{qst}}, \mathrm{B}_{\mathrm{qst}}$ & \\
\hline $\begin{array}{l}\text { Dynamic reaction of } \\
\text { the vehicle }\end{array}$ & $\begin{array}{l}\ddot{y}^{*}, \ddot{z}^{*}, \mathrm{rms} \ddot{y}^{*}, \\
\mathrm{rms} \ddot{z}^{*}\end{array}$ & \multicolumn{2}{|c|}{$\ddot{y}_{q}^{*}, \ddot{z}_{q}^{*}, \mathrm{rms} \ddot{y}_{q}^{*}, \mathrm{rms} \ddot{z}_{q}^{*}, \ddot{y}_{q s t}^{*}$} \\
\hline
\end{tabular}

Meaning of symbols used in table:

$Y$ - transverse force of influence of wheel on the track,

$Q$ - vertical force of influence of wheel on the track,

$H$ - transverse force of influence of wheel set on the track,

$Y_{q s t}$ - quasi-static transverse force of influence of the wheel on the track,

$Q_{q s t}$ - quasi-static vertical force of influence of the wheel on the track,

$B_{q s t}$ - quasi-static force of influence on the track in the curves,

$\ddot{y}^{*}$ - transverse acceleration on the vehicle box(?),

$\ddot{y}_{S}^{+}-$transverse acceleration on the truck trolley, 
$\ddot{y}_{S}^{*}$ - transverse acceleration on the vehicle box,

$\ddot{y}_{q}{ }^{*}$ - quasi-static transverse acceleration on the vehicle box,

$\ddot{y}_{q s t}{ }^{*}-$ quasi-static transverse acceleration on the vehicle box,

$\ddot{z}^{*}$ - vertical acceleration on the vehicle box,

$\ddot{z}_{S}{ }^{*}$ - vertical acceleration on the vehicle box,

$\ddot{z}_{q}{ }^{*}$ - quasi-static vertical acceleration on the vehicle box,

$\eta$ - overturn of the vehicle factor,

rms - mid-squared value of the height

The first publication did not contain division on normal and simplified research method. That division appeared from second publication (October, 1999). The normal measurement method (research) it is about measuremnt contact forces $\mathrm{Q}$ and $\mathrm{Y}$ in contact area of a wheel with a track and acceleration on other wheel sets/trolleys and on vehicle box.

Simplified measurement method is about mensuration of the transverse forces $\mathrm{H}$ running between a wheel set and axle box and also acceleraion on other wheel sets/trolleys and on the vehicle box. Application of this method is shown on the picture No. 1. Second variant of simplified method is about acceleration measurement being turned off. Criteria such as: innovativeness of the truck construction, type of the running gear, maximum speed, static pressure on the axis, admissible deficiency of the superelevation described in chart UIC or in norm decides about choosing method. Measured size before further treatment are subject to filtration by suitable filters.

Acceptable values of individual parameters, behind the norm PN-EN 14363, are given in table No.3.

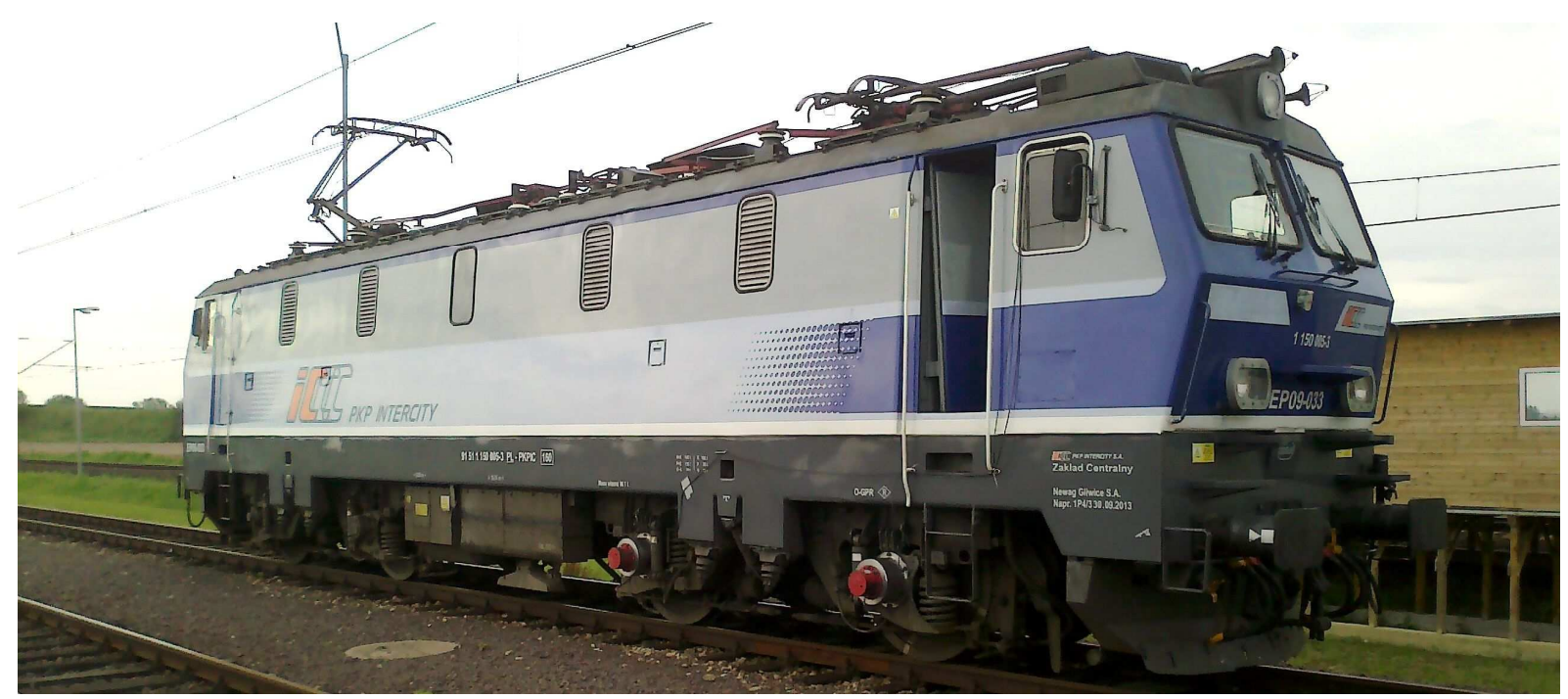

1. Measurement of $\mathrm{H}$ factor according to simplified method (fot. Grzegorz Wysocki) 
Tab. 3. Acceptable values of individual parameters according to PN-EN 14363

\begin{tabular}{|c|c|}
\hline Parameter & Wartość dopuszczalna \\
\hline Amount of leading forces $\Sigma Y$ & $\begin{array}{l}\left.\mathrm{k}_{1}\left(10+2 \mathrm{Q}_{0} / 3\right)^{*}{ }^{*}\right) \\
\mathrm{k}_{1}=0,85-\text { wagony towarowe } \\
\mathrm{k}_{1}=1-\text { pozostałe pojazdy }\end{array}$ \\
\hline Quotient of the forces leading and vertical Y/Q & 0,8 \\
\hline Instability (RMS $\Sigma Y$ ) & $(\Sigma \mathrm{Y}) / 2$ \\
\hline Transverse forces $\mathrm{H}$ & $\begin{array}{l}\mathrm{k}_{2}\left(10+2 \mathrm{Q}_{0} / 3\right){ }^{* 1)} \\
\mathrm{k}_{2}=0,75-\text { wag. tow. próżne } \\
\mathrm{k}_{2}=0,8-\text { wag. tow. ładowne } \\
\mathrm{k}_{2}=0,9-\text { pozostałe pojazdy }\end{array}$ \\
\hline Instability (RMS H) & $\mathrm{H} / 2$ \\
\hline $\begin{array}{l}\text { Vertical force on the wheel Q } \\
\text { - for straight and in curves with big radius } \\
\cdot \mathrm{V}_{\lim } \leq 160 \mathrm{~km} / \mathrm{h} \\
\cdot 160 \mathrm{~km} / \mathrm{h}<\mathrm{V}_{\lim } \leq 200 \mathrm{~km} / \mathrm{h} \\
\cdot 200 \mathrm{~km} / \mathrm{h}<\mathrm{V}_{\lim } \leq 250 \mathrm{~km} / \mathrm{h} \\
\cdot 250 \mathrm{~km} / \mathrm{h}<\mathrm{V}_{\lim } \leq 300 \mathrm{~km} / \mathrm{h} \\
\cdot \mathrm{V}_{\lim }>300 \mathrm{~km} / \mathrm{h} \\
\text { - for curves with short radius } 250 \mathrm{~m}<\mathrm{R}<600 \mathrm{~m} \\
\text { - for every section } \mathrm{i} \mathrm{V}_{\text {lim }} \leq 100 \mathrm{~km} / \mathrm{h} \text { i } 225 \mathrm{kN}<\mathrm{P}_{0} \leq 250 \mathrm{kN}{ }^{* 3)}\end{array}$ & $\begin{array}{l}\left.\min \mathrm{z}\left(90+\mathrm{Q}_{0}\right) \text { lub } 200 \mathrm{kN}^{* 1}\right) \\
\min \mathrm{z}\left(90+\mathrm{Q}_{0}\right) \text { lub } 190 \mathrm{kN}{ }^{* 1)} \\
\min \mathrm{z}\left(90+\mathrm{Q}_{0}\right) \text { lub } 180 \mathrm{kN}{ }^{* 1)} \\
\min \mathrm{z}\left(90+\mathrm{Q}_{0}\right) \text { lub } 170 \mathrm{kN}^{* 1)} \\
\min \mathrm{z}\left(90+\mathrm{Q}_{0}\right) \text { lub } 160 \mathrm{kN}^{* 1} \\
\min \mathrm{z}\left(90+\mathrm{Q}_{0}\right) \text { lub } 200 \mathrm{kN}{ }^{* 1)} \\
\min \mathrm{z}\left(90+\mathrm{Q}_{0}\right) \operatorname{lub} 210 \mathrm{kN}{ }^{* 1)}\end{array}$ \\
\hline Quasi-static leading force $\mathrm{Y}_{\mathrm{qst}}$ & $60 \mathrm{kN}$ \\
\hline $\begin{array}{l}\text { Quasi-static vertical force on the wheel } \mathrm{Q}_{\mathrm{qst}} \\
\left.\text { - for } \mathrm{P}_{0} \leq 225 \mathrm{kN}^{* 3}\right) \\
\text { - for } 225 \mathrm{kN}<\mathrm{P}_{0} \leq 250 \mathrm{kN}^{* 3)}\end{array}$ & $\begin{array}{l}145 \mathrm{kN} \\
155 \mathrm{kN}\end{array}$ \\
\hline Factor of vehicle overset (for $\left.\mathrm{I}_{\mathrm{adm}}>165 \mathrm{~mm}\right)-\eta$ & 1 \\
\hline Transverse acceleration on the trolley frame $\left(\ddot{y}_{s}^{+}\right)_{\lim }$ & $12-\mathrm{M}_{\mathrm{b}} / 5^{* 2)}$ \\
\hline $\begin{array}{l}\text { Transverse acceleration on the box }\left(\ddot{y}_{s}^{*}\right)_{\text {lim }} \\
\text { - for traction vehicle and passenger rolling stock } \\
\text { · on straight and in curves with big radius } \\
\text { · in curves with small radius } 400 \mathrm{~m}<\mathrm{R}<600 \mathrm{~m} \\
\text { - in curves with small radius } 250 \mathrm{~m}<\mathrm{R}<400 \mathrm{~m} \\
\text { - for freight wagon } \\
\text { - for wagon vehicle } \\
\text { - for non-wagon vehicle dla } \mathrm{P}_{0} \geq 200 \mathrm{kN}^{* 3)} \\
\text { - for non-wagon vehicle dla } 60 \mathrm{kN}<\mathrm{P}_{0}<200 \mathrm{kN}^{* 3)} \\
\text { - for non-wagon vehicle dla } \mathrm{P}_{0} \leq 60 \mathrm{kN}^{* 3)}\end{array}$ & $\begin{array}{c}3 \mathrm{~m} / \mathrm{s}^{2} \\
2,8 \mathrm{~m} / \mathrm{s}^{2} \\
2,6 \mathrm{~m} / \mathrm{s}^{2} \\
\\
3 \mathrm{~m} / \mathrm{s}^{2} \\
3 \mathrm{~m} / \mathrm{s}^{2} \\
4,43-\mathrm{P}_{0} / 140 \\
4 \mathrm{~m} / \mathrm{s}^{2}\end{array}$ \\
\hline $\begin{array}{l}\text { Vertical acceleration on the box }\left(\ddot{z}_{s}^{*}\right)_{\lim } \\
\text { - for traction vehicle and passenger rolling stock } \\
\text { - with two-level springs } \\
\text { - with one-level spring } \\
\text { - with pneumatic springs without an air } \\
\text { - for freight wagon }\end{array}$ & $\begin{array}{l}3 \mathrm{~m} / \mathrm{s}^{2} \\
5 \mathrm{~m} / \mathrm{s}^{2} \\
5 \mathrm{~m} / \mathrm{s}^{2} \\
5 \mathrm{~m} / \mathrm{s}^{2}\end{array}$ \\
\hline Stability on the trolley frame $\operatorname{RMS}\left(\ddot{y}_{s}^{+}\right)_{\lim }$ & $\left(\ddot{y}_{s}^{+}\right)_{\lim / 2}$ \\
\hline Stability on the axle box for non-wagon vehicle RMS $\left(\ddot{y}_{s}\right)_{\text {lin }}$ & $5 \mathrm{~m} / \mathrm{s}^{2}$ \\
\hline
\end{tabular}


Transverse acceleration on the box $\left(\ddot{y}_{q}^{*}\right)_{\lim }$

- locomotive (without maneuvering) and motor coach

- locomotive maneuvering

- a complex of traction and passenger rolling stock

- trolley freight wagons vacant

- trolley freight wagons loaded

- non-trolley freight wagons vacant

- non-trolley freight wagons loaded

Vertical acceleration on the box $\left(\ddot{z}_{q}^{*}\right)_{\lim }$

- locomotive (without maneuvering) and motor coach

- locomotive maneuvering

- a complex of traction and passenger rolling stock

- trolley freight wagons vacant

- trolley freight wagons loaded

- non-trolley freight wagons vacant

- non-trolley freight wagons loaded

${ }^{*}{ }^{* 1} \mathrm{Q}_{0}$ - impact on the wheel [kN]; ${ }^{* 2)} \mathrm{M}_{\mathrm{b}}$ tolley mass- $[\mathrm{t}] ;{ }^{* 3)} \mathrm{P}_{0}-$ static impact on the axis [kN]

\section{Measurement techniques used in Instytut Kolejnictwa}

Laboratorium Badań Taboru Instytutu Kolejnictwa from beginning of apperance of UIC 518 chart implemented the research methods presented in it at the same time measurement techniques which should cope to upturned research tasks. During the period preceding the introduction this Laboratory chart worked on implementation measurement technique, relying on measuring forces $\mathrm{Q}$ (vertical) and Y (transverse) in the wheel and track contact area during the ride.

Attempts of implementation of measurement of contact forces $\mathrm{Q}$ and $\mathrm{Y}$ at the contact of the wheel and track began in IK in 1977 (then Centralny Ośrodek Badań i Rozwoju Techniki Kolejnictwa). At the beginning that measurement based on tension of the disk of the wheel, created by distortions of the disk under influence of Q and Y forces. This method, implemented in 1980, back then was not accurated and characterized by eddying of output signal, dependency of reading of force $\mathrm{Q}$ value upon set's curve rotation and visible influence $\mathrm{Q}$ force on $\mathrm{Y}$ force.

Next implementation step of measurement of contact forces Q and Y was attempt of define those forces based on tension measurement on spoke of wheels taken in 1982. Because of huge influence of reading $\mathrm{Q}$ and $\mathrm{Y}$ forces and contrawise, this method did not find any usage.

In 1987 IK (then Centrum Naukowo-Techniczne Kolejnictwa) form cooperation with researching institute Niemieckich Kolei Federalnych in Minden, then use developed documentation, began implementing measurement method of contact forces $\mathrm{Q}$ and $\mathrm{Y}$ based on measurement of bending moment on the axis of wheel set [4]. To enable of reading and saving measure contact forces, in Laboratorium Badań Taboru was created the appropriate electronic device, initially based on analogue processing measurement signals, then from 2001 - on digital processing. For treatment of measure of force and acceleration specialised software was bought, created on the basis of guidelines developed by Pracownie Obliczeń i Rozwoju Technik Pomiarowych w Laboratorium Badań Taboru. Colaterally in Instytut Kolejnictwa new head assembled on the measurement axis of wheel sets (picture 2) was developed and created. In those heads applied new type, maintenancefree collectors which improve the quality of signals transmission. 


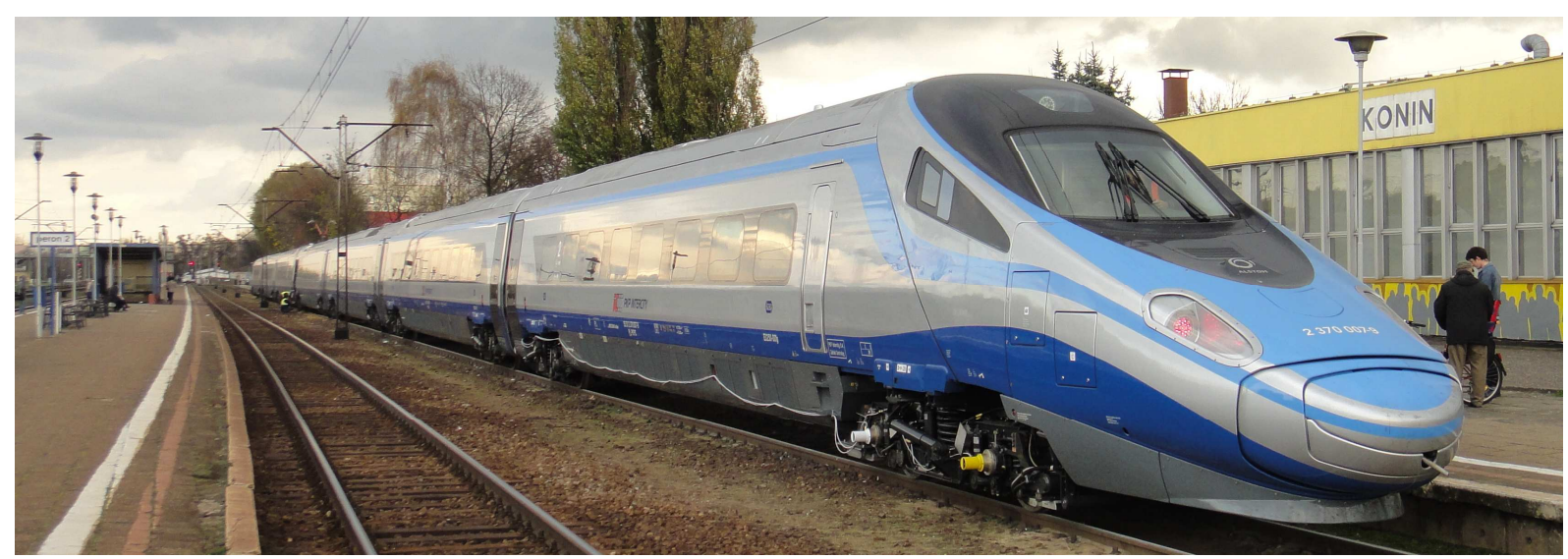

2. New heads for QY forces on the measurement set of Pendolino (fot. Andrzej Zbieć)

Research of dynamic and safety of ride and influence on the vehicle track according to UIC 518 chart and PN-EN 14363 norm is basic research, informing about safety of the ride and mutual influence between track vehicle with track. Researches are conducting by basis in two capacity ways (vacant and loaded), but for vehicles equipped with air spring - additionally in degraded way (air springs without an air). Obtained as a result of static processing results are compared with criterial sizes.

According to requirements above mentioned chart and norm, to obtain complete image of vehicle behavior, researches of ride dynamic should be run on following parts of the track: straight and curves with very huge radius, curves with big radius, curves with small radius $(400-600 \mathrm{~m})$ and curves with very small radius $(250-400 \mathrm{~m})$. Researches should be run on tracks with declined rail course 1:20 and 1:40. Full measurement procedure assume the examination of rail vehicle in all of above mentioned sections and declinations of rail courses and different capacity ways. In some cases it is acceptable to lead the researches on the choosen section or decline of rail course or in the same capacity way.

Because of possibility of comparability researches done on different railroad network and normalize terms of researches was defined the parameters determine the condition of track maintain, on which the researches are conducted, because the track maintain and its geometrical parameters influence in the prime way in the rail vehicle movement and level of mechanical vibration encountered on the researched object. For evaluation of track maintain three parameters was defined - QN1, QN2 and QN3, characterise vertical and transverse track inequalities:

- QN1 - value of inequality, demanding observation of the track or engage measures remedial in within normal plan of track maintaining services.

- QN2 - value of inequality, qualified the track to quick engage measure remedial

- QN3 - value of inequality, suit to still acceptable state of the track, however distinct than typical value, characterised the condition of track.

Measurements made on sections with value witch overdraw QN3 are not taken for the next part of processing and rating. Mximal values of vertical and transverse inequalities are given in information purposes also in possiblity of eliminate section about values overdraw QN3. Whereas quality of the track defined is by standard departures of those sizes. Maximal value of vertical and transverse inequalities QN3 is given in table 4, values of standard departures of the track, on which the researches should be done are given in table $\mathbf{5}$. 
Tab. 4. Maximum values of vertical and transverse irregularities

\begin{tabular}{|c|c|c|}
\hline \multicolumn{3}{|c|}{ The maximum value of inequality QN3 [mm] } \\
\hline & Vertical & transverse \\
\hline $\mathrm{v} \leq 120 \mathrm{~km} / \mathrm{h}$ & 16 & 13,0 \\
\hline $120<\mathrm{v} \leq 160 \mathrm{~km} / \mathrm{h}$ & 13 & 10 \\
\hline $160<\mathrm{v} \leq 200 \mathrm{~km} / \mathrm{h}$ & 12 & 9 \\
\hline $200<\mathrm{v} \leq 300 \mathrm{~km} / \mathrm{h}$ & 10 & 8 \\
\hline
\end{tabular}

Tab. 5. Values of deviations of standard vertical and transverse irregularities

\begin{tabular}{|r|c|c|c|c|}
\hline \multicolumn{4}{|c|}{ Standard deviation inequality $[\mathrm{mm}]$} \\
& \multicolumn{2}{|c|}{ vertical } & \multicolumn{2}{c|}{ transverse } \\
\hline & $\min$ & $\max$ & $\min$ & $\max$ \\
\hline $\mathrm{v} \leq 120 \mathrm{~km} / \mathrm{h}$ & 1,80 & 2,50 & 1,05 & 1,45 \\
\hline $120<\mathrm{v} \leq 160 \mathrm{~km} / \mathrm{h}$ & 1,40 & 1,85 & 0,75 & 1,00 \\
\hline $160<\mathrm{v} \leq 200 \mathrm{~km} / \mathrm{h}$ & 1,15 & 1,60 & 0,70 & 0,90 \\
\hline $200<\mathrm{v} \leq 230 \mathrm{~km} / \mathrm{h}$ & 1,05 & 1,45 & 0,65 & 0,80 \\
\hline $230<\mathrm{v} \leq 300 \mathrm{~km} / \mathrm{h}$ & 0,85 & 1,15 & 0,50 & 0,65 \\
\hline
\end{tabular}

\section{Processing and results rating}

Recorded measurement data are subjects of statistic processing. Method of processing individual parameters are accomplished based on table $\mathbf{6}$. 
Tab. 6. List of signal processing

\begin{tabular}{|c|c|c|c|c|c|c|}
\hline \multirow{3}{*}{ Size } & \multirow{3}{*}{ Filter } & \multicolumn{2}{|c|}{$\begin{array}{c}\text { Statistical processing for } \\
\text { sections }\end{array}$} & \multirow{2}{*}{\multicolumn{3}{|c|}{$\begin{array}{c}\text { Statistical processing for the measuring } \\
\text { section }\end{array}$}} \\
\hline & & \multirow[b]{2}{*}{$\begin{array}{c}\text { Measurement } \\
\text { method }\end{array}$} & \multirow[b]{2}{*}{ Quantile } & & & \\
\hline & & & & Straight & $\begin{array}{l}\text { Curve } \\
\text { with } \\
\text { big R }\end{array}$ & $\begin{array}{l}\text { Curve } \\
\text { with } \\
\text { small R }\end{array}$ \\
\hline$(\Sigma Y)$ & \multirow{3}{*}{\multicolumn{2}{|c|}{$\begin{array}{l}20 \mathrm{~Hz} \\
\text { Moving average: } \\
\text { - droga } 2 \mathrm{~m} \\
\text { - poskok } \leq 0,5 \mathrm{~m}\end{array}$}} & \multirow{3}{*}{$\begin{array}{c}F_{1}=0,15 \% \\
F_{2}=99,85 \%\end{array}$} & 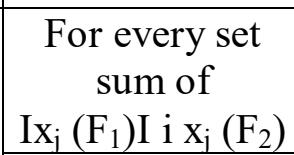 & \multirow{3}{*}{\multicolumn{2}{|c|}{$\begin{array}{l}\text { For every set sum of } \\
\text { - right curve } x_{j}\left(F_{2}\right) \\
\text { - left curve } \mathrm{Ix}_{\mathrm{j}}\left(\mathrm{F}_{1}\right) \mathrm{I} \\
\text { Sum for } \\
\text { - prawy łuk } \mathrm{x}_{\mathrm{j}}\left(\mathrm{F}_{2}\right) \\
\text { - lewy huk Ix } \mathrm{x}_{\mathrm{j}}\left(\mathrm{F}_{1}\right) \mathrm{I}\end{array}$}} \\
\hline $\mathrm{Y} / \mathrm{Q}$ & & & & \multirow[t]{2}{*}{ 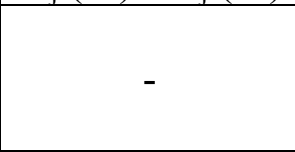 } & & \\
\hline $\mathrm{H}$ & & & & & & \\
\hline$\ddot{y}_{S}^{+}$ & $10 \mathrm{~Hz}$ & & \multirow{3}{*}{$\begin{array}{c}F_{1}=0,15 \% \\
F_{2}=99,85 \%\end{array}$} & 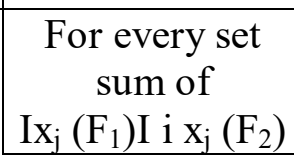 & \multicolumn{2}{|c|}{$\begin{array}{l}\text { For every set sum of } \\
\text { - right curve } x_{j}\left(F_{2}\right) \\
\text { - left curve } \operatorname{Ix}_{j}\left(F_{1}\right) I\end{array}$} \\
\hline$\ddot{y}_{S}^{*}$ & $6 \mathrm{~Hz}$ & & & 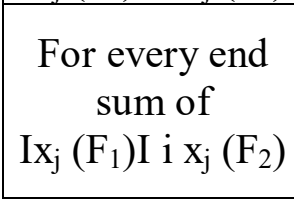 & \multicolumn{2}{|c|}{$\begin{array}{l}\text { Dla każdego końca } \\
\text { suma } \\
\text { - right curve } x_{j}\left(F_{2}\right) \\
\text { - left curve } \mathrm{Ix}_{\mathrm{j}}\left(\mathrm{F}_{1}\right) \mathrm{I}\end{array}$} \\
\hline$\ddot{z}_{S}^{*}$ & $\begin{array}{c}0,4 \div 10 \\
\mathrm{~Hz}\end{array}$ & & & - & \multicolumn{2}{|c|}{$\begin{array}{l}\text { Dla każdego końca } \\
\text { suma } \\
\text { - right curve } \mathrm{x}_{\mathrm{j}}\left(\mathrm{F}_{2}\right) \\
\text { - left curve } \mathrm{Ix}_{\mathrm{j}}\left(\mathrm{F}_{1}\right) \mathrm{I}\end{array}$} \\
\hline $\mathrm{Y}_{\mathrm{qst}}$ & \multirow{3}{*}{$>20 \mathrm{~Hz}$} & & \multirow[t]{2}{*}{$\mathrm{F}_{0}=50 \%$} & \multirow[t]{2}{*}{ - } & \multicolumn{2}{|c|}{$\begin{array}{l}\text { For every set sum of } \\
\text { - right curve } x_{j}\left(F_{0}\right) \\
\text { - left curve } \mathrm{Ix}_{\mathrm{j}}\left(\mathrm{F}_{0}\right) \mathrm{I}\end{array}$} \\
\hline $\mathrm{Q}_{\mathrm{qst}}$ & & & & & \multirow{2}{*}{\multicolumn{2}{|c|}{$\begin{array}{l}\text { For every set sum of } \\
\text { external wheels on } \\
\text { the curve } x_{j}\left(F_{2}\right)\end{array}$}} \\
\hline Q & & & $\mathrm{F}_{2}=99,85 \%$ & $\begin{array}{l}\text { For every set } x_{j} \\
\qquad\left(F_{2}\right) \\
\text { sum of } 1 \text { do } 4\end{array}$ & & \\
\hline$\ddot{y}_{q}^{*} \mathrm{i} \quad \ddot{z}_{q}^{*}$ & $\begin{array}{c}0,4 \div 10 \\
\mathrm{~Hz}\end{array}$ & & $\begin{array}{c}F_{1}=0,15 \% \\
F_{2}=99,85 \%\end{array}$ & \multicolumn{3}{|c|}{$\begin{array}{l}\text { For every end sum of } \\
\operatorname{Ix}_{\mathrm{j}}\left(\mathrm{F}_{1}\right) \mathrm{I} i \mathrm{x}_{\mathrm{j}}\left(\mathrm{F}_{2}\right)\end{array}$} \\
\hline
\end{tabular}

Obtained results are compared with appropriate criterial values. On picture 3-10 examplary results are presented. 

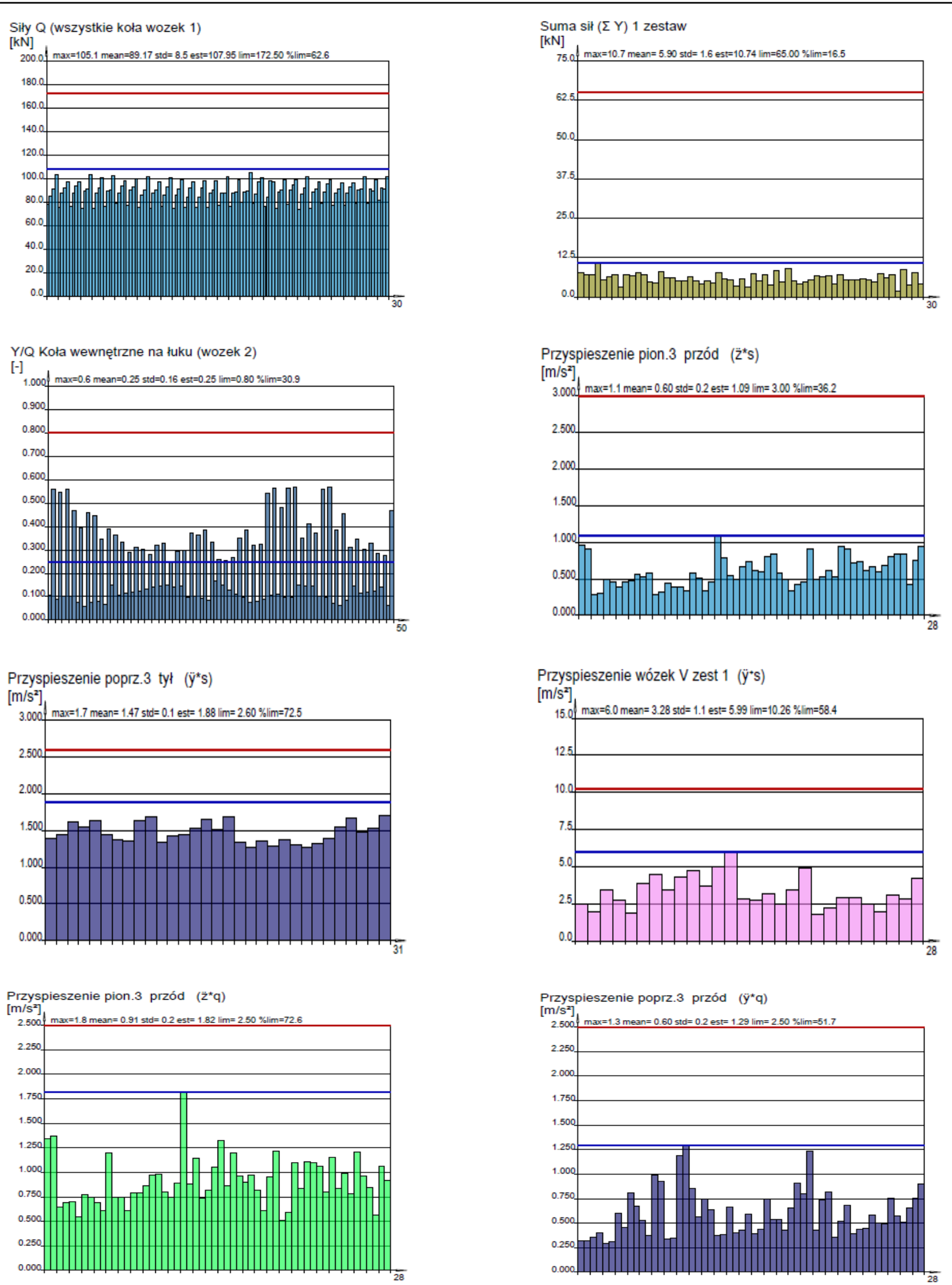

$3 \div \mathbf{1 0}$. Sample of the results in graphs form IK researches

\section{Source materials}

[1] Cichocki Z. i in. „Rozwój metod badawczych własności mechanicznych taboru w sześćdziesięcioletniej historii Instytutu Kolejnictwa”, Problemy Kolejnictwa, Zeszyt 153, s. 93-116, Warszawa 2011

[2] Karta UIC 513 „Guidelines for evaluating passenger comfort in relation to vibration in 
railway vehicles", wydanie I, 1.07.1994

[3] Karta UIC 518 „Testing and approval of railway vehicles from the point of view of their dynamic behaviour - Safety - Track fatigue - Ride quality”, wydanie IV, wrzesień 2009

[4] Laboratorium Badań Taboru CNTK, „Opis metod pomiaru sił na styku koło szyna stosowanych w CNTK”, Warszawa, marzec 2003\

[5] PN-EN 12299:2009 „Kolejnictwo - Komfort jazdy pasażerów - Pomiary i ocena”

[6] PN-EN 14253+A1:2011 „Drgania mechaniczne - Pomiar i obliczanie zawodowej ekspozycji na drgania o ogólnym działaniu na organizm człowieka dla potrzeb ochrony zdrowia Wytyczne praktyczne"

[7] PN-EN 14363:2016-04 „Kolejnictwo - Badania i symulacje modelowe właściwości dynamicznych pojazdów szynowych przed dopuszczeniem do ruchu - Badania właściwości biegowych i próby stacjonarne

[8] PN-EN 16235:2013-12 „Kolejnictwo - Badania właściwości dynamicznych pojazdów szynowych przed dopuszczeniem do ruchu - Wagony towarowe - Warunki do zwolnienia wagonów towarowych o określonych właściwościach z badań liniowych zgodnie z EN 14363

[9] Rozporządzenie Ministra Gospodarki i Pracy $z$ dnia 5 sierpnia 2005 w sprawie bezpieczeństwa i higieny pracy przy pracach związanych z narażeniem na hałas lub drgania mechaniczne (Dz. U. nr 157, poz. 1318)

[10] Załącznik nr 2 do Rozporządzenia Ministra Pracy i Polityki Społecznej z dnia 29.11.2002 w sprawie najwyższych dopuszczalnych stężeń i natężeń czynników szkodliwych dla zdrowia w środowisku pracy (Dz. U. nr 217, poz. 1833 z późn. zm.) 